\title{
A Forecast of Targeting Leukemia Stem Cells by Nanomedicine
} Xiangwei Huang ${ }^{1,2}$, Xunlei Kang ${ }^{3^{*}}$ and Meng Zhao $0^{1,2,4, *}$

${ }^{1}$ The Third Affiliated Hospital, Zhongshan School of Medicine, Sun Yat-Sen University, China

${ }^{2}$ Key Laboratory for Stem Cells and Tissue Engineering, Ministry of Education, Sun Yat-Sen University, China

${ }^{3}$ Department of Medicine, University of Missouri School of Medicine, USA

${ }^{4}$ Department of Pathophysiology, Sun Yat-Sen University, China

\begin{abstract}
Leukemia Stem Cells (LSCs) are a subpopulation of leukemic cells that display characteristics of self-renewal, differentiation and tumor-initiating capacity. They are also thought to be responsible for Chemoradiotherapy resistance and the recurrence of leukemia. Recently, Nanomedicine has been widely used for cancer treatments with improved targeting efficiency and reduced side effects. In this review, we have summarized the studies of LSCs identification and therapeutic strategies with a commentary on recently developed cancer stem cell and LSCs targeting strategies by Nanomedicine.
\end{abstract}

Keywords: Nanomedicine; Nanocarrier; Cancer therapy; Leukemia stem cells; Cancer stem cells

\section{Introduction}

Cancer Stem Cells (CSCs) are a subset of cancer cells with selfrenewal, differentiation and tumor-initiating properties. They are considered as the leading cause of tumor initiation, promotion, and relapse in most types of cancers [1]. The first experimental evidence for CSCs was given by Bonnet and Dick in 1997. They found that single CD $34^{+} \mathrm{CD} 38^{-}$Acute Myeloid Leukemia (AML) cell was able to initiate AML in NOD-SCID mice [2]. Furthermore, this small subset population was found to be responsible for chemotherapy and radiotherapy resistance because CSCs have enhanced DNA repair ability, enriched anti-apoptotic proteins, improved drug efflux transporters, and are protected in specific microenvironment or niche [2]. Therefore, these leukemia initiating cells (LIC) or leukemia Stem Cells (LSCs) are considered as a critical target for leukemia therapy. Subsequently, CSCs in solid tumors have been identified from brain, prostate, breast, colon, and pancreas cancer [2].

Traditional cancer treatments, such as Chemotherapy and Radiotherapy, are cytotoxic to both normal and cancerous cells, which cause severe side effects, like bone marrow suppression, cardiomyopathy, and neurotoxicity. These side effects significantly limit their tumor therapeutic applications in clinic $[3,4]$. Recently, developed nanoscale devices have been used for drug delivery in clinic, because these nanoparticles are within 100 nanometers and can readily interact with biomolecules on the cell surface or within the cells. They can improve the drug delivery efficiency and stability in vivo [5]. This nanotechnology based drug delivery strategy has opened a novel avenue for cancer treatment and particularly improved the feasibility of CSCs targeting therapy in vivo [6].

Nanomedicine is the medical applications of nanothechnology. There are several applications of Nanomedicine by using nanomaterials in clinic inducing in vivo medical imaging for diagnosis and drug delivery for therapy [6]. In this review, we are focusing on the Nanomedicine involved targeted therapy particularly with a comment on the future applications of Nanomedicine in LSC treatment.

\section{Leukemia Stem Cells}

Like Hematopoietic Stem Cells (HSCs), LSCs are thought to reside at the apex of the leukemia hierarchy. LSCs give rise to leukemic progenitors and leukemic blasts with reduced capacity to self-renew and differentiate [7-9]. Studies suggested that LSCs originate from HSCs or progenitor cells. For example, BCR/ABL1, an oncogenic tyrosine kinase in Chronic Myeloid Leukemia (CML), can be detected in several hematopoietic lineages [10,11]. DNMT3a mutations, common oncogenic mutation in AML are found in HSCs, progenitor and mature cell [12]. These studies indicated that leukemic genetic alterations might be initiated from stem cells and accumulate in committed progenitors and mature blood cells during differentiation, which eventually initiate leukemogenesis.

\section{Identification of Leukemia Stem Cell Surface Markers}

Identifying specific LSC specific markers is extremely helpful to develop new therapeutic strategies for LSC targeting therapy. However, previous evidence suggested that LSCs share similar cell surface markers with normal HSCs in mouse and human leukemia models [13]. Human LSCs were first identified as CD34+CD38- clones, which overlap with normal HSCs [14]. Recent progresses have identified several novel surface markers, which can distinguish LSCs from normal HSCs, such as CD44 [15], CD123 [16], CLL-1 [17], TIM-1 [18], CD96 [19], CD47 [20]. In the following section, we will review several cell surface markers for LSC identification.

CD44 is a transmembrane glycoprotein that acts as a receptor for hyaluronan acid (HA) and other receptors, including osteopontin, collagens, Matrix Metalloproteinases (MMPs) [21]. CD44 is highly expressed in $\mathrm{CD} 34^{+} \mathrm{CD} 38^{-} \mathrm{AML}$ cells. Jin et al. reported that CD44 antibody could significantly reduce LSC numbers and prolong survival

*Corresponding authors: Dr. Meng Zhao, The Third Affiliated Hospital, Zhongshan School of Medicine, Key Laboratory for Stem Cells and Tissue Engineering, Ministry of Education , Department of Pathophysiology, Zhongshan School of Medicine, Sun Yat-Sen University, Guangzhou, China, Tel: +86 20 8411 2828; E-mail: zhaom38@mail.sysu.edu.cn

Prof. Xunlei Kang, Department of Medicine, University of Missour School of Medicine, Columbia, MO, USA, Tel: +1 573-882-1566; E-mail: kangxu@health.missouri.edu

Received April 01, 2017; Accepted April 28, 2017; Published May 08, 2017

Citation: Huang X, Kang X, Zhao M (2017) A Forecast of Targeting Leukemia Stem Cells by Nanomedicine. J Stem Cell Res Ther 7: 385. doi: 10.4172/2157-7633.1000385

Copyright: @ 2017 Huang X, et al. This is an open-access article distributed under the terms of the Creative Commons Attribution License, which permits unrestricted use, distribution, and reproduction in any medium, provided the original author and source are credited. 
in AML xenograft mouse model. Furthermore, leukemic cells obtained from CD44 antibody treated mice failed to develop leukemia which indicates that CD44 is critical for the self-renewal maintenance of LSCs [15]. CD123 is known as interleukin 3 receptor, alpha (IL- 3R $\alpha$ ). Jordan et al. first found CD123 was highly expressed in $\mathrm{CD} 34^{+} \mathrm{CD} 38^{-}$cells from AML specimens but not from normal $\mathrm{BM}$ derived $\mathrm{CD} 34^{+} \mathrm{CD} 38^{-}$cells. Functionally, $\mathrm{CD} 34^{+} \mathrm{CD} 123^{+}$cells have competitive leukemogenesis capacity [22]. Consistent with this, high CD123 expression was detected in AML and CML patients [23]. CLL-1 is a type II transmembrane glycoprotein and belongs to C-type lectin-like receptor family. CLL1 was found specifically enriched in $\mathrm{CD} 34^{+} \mathrm{CD} 38^{-}$LSCs in AML patients (77 out of 89 positive). CD34+CLL- $1^{+}$cells can initiate AML in immunocompromised mice and interestingly CLL-1 expression is completely absent on $\mathrm{CD} 34^{+} \mathrm{CD} 38^{-}$cells from normal controls [24]. T cell immunoglobulin mucin-3 (TIM-3), is highly expressed in AML LSCs but absent in normal HSCs. Furthermore, TIM- $3^{+}$but not TIM-3-AML cells can reconstitute human AML in immune-deficient mice [25,26]. Similarly, CD96 and CD47 are also highly expressed in CD $34^{+}{ }^{-}$D $38^{-}$AML cells but weakly expressed in the normal HSCs [19]. Increased CD47 expression is correlated with poor survival in three independent cohorts of adult AML patients [20]. CD32 and CD25 were suggested to be associated with Chemotherapy-resistant capacity in human AML LSCs [27], however further LSC markers need to be developed for efficient LSC targeting. These data demonstrated that LSCs can be distinguished from normal HSCs basing on cell surface markers. We have summarized the reported LSCs markers with their LSCs targeting potential in Figure 1.

\section{Therapeutic Strategies for LSCs Targeting Strategies}

Because traditional cytotoxic chemotherapies often kill rapidly dividing normal cells, the primary goal of targeted therapies is to eliminate cancer and cancer stem cells more precision with less side effects. Besides all the targeted therapies, monoclonal antibody and small molecule therapies have achieved the most promising anti-tumor results
[28]. Monoclonal antibody treatments have remarkable specificity for target therapies and their side effects are well limited. Small molecular are more efficient and cost-effective compared to antibody therapies, however how to select and modify the best compound for targeting is still challenging in the field [29]. Targeting LSCs, which are maintained by self-renewal, is expected to eradicate leukemia and reduce recurrence [9]. With the increased understanding of LSCs, recently several promising therapeutic strategies have been developed to target LSCs, such as targeting cell surface antigens, signaling transduction and the niche of LSCs (Table 1).

\section{Targeting Antigens on LSCs}

Monoclonal antibodies are the best candidates for cell surface antigen targeting therapy [30]. Anti-CD44 and anti-CD123monoclonal antibodies have been used for LSC targeting in AML mouse model, in which LSCs cannot home to their BM protective niche $[15,16]$. AntiCD47 and Anti-Tim-3 can decrease LSC proliferation in AML xenograft models [25,31]. Notably, in most cases antibody based therapeutic strategies can specifically target LSCs but spare normal HSCs.

\section{Targeting Signaling Transduction in LSCs}

Both LSCs and normal HSCs are maintained by self-renewal, which is regulated by multiple key signals. How to distinguish the self-renewal signals between normal HSCs and LSCs is critical for developing novel LSCs targeting strategies $[32,33]$.

Recently, several key signals have been identified for LSC selfrenewal maintenance including Wnt, Hedgehog, and Notch signal pathways. The $\mathrm{Wnt} / \beta$-catenin pathway is hyper-activated in different forms of AML [34]. Loss of $\beta$-Catenin impairs self-renewal of LSCs in CML, with BCR-ABL fusion protein mutation [35,36], however, normal hematopoiesis was maintained in mouse models [37,38]. High level $\beta$-catenin was considered to be critical for leukemia initiation and drug resistance. Inhibition or deletion of $\beta$-catenin reduced the

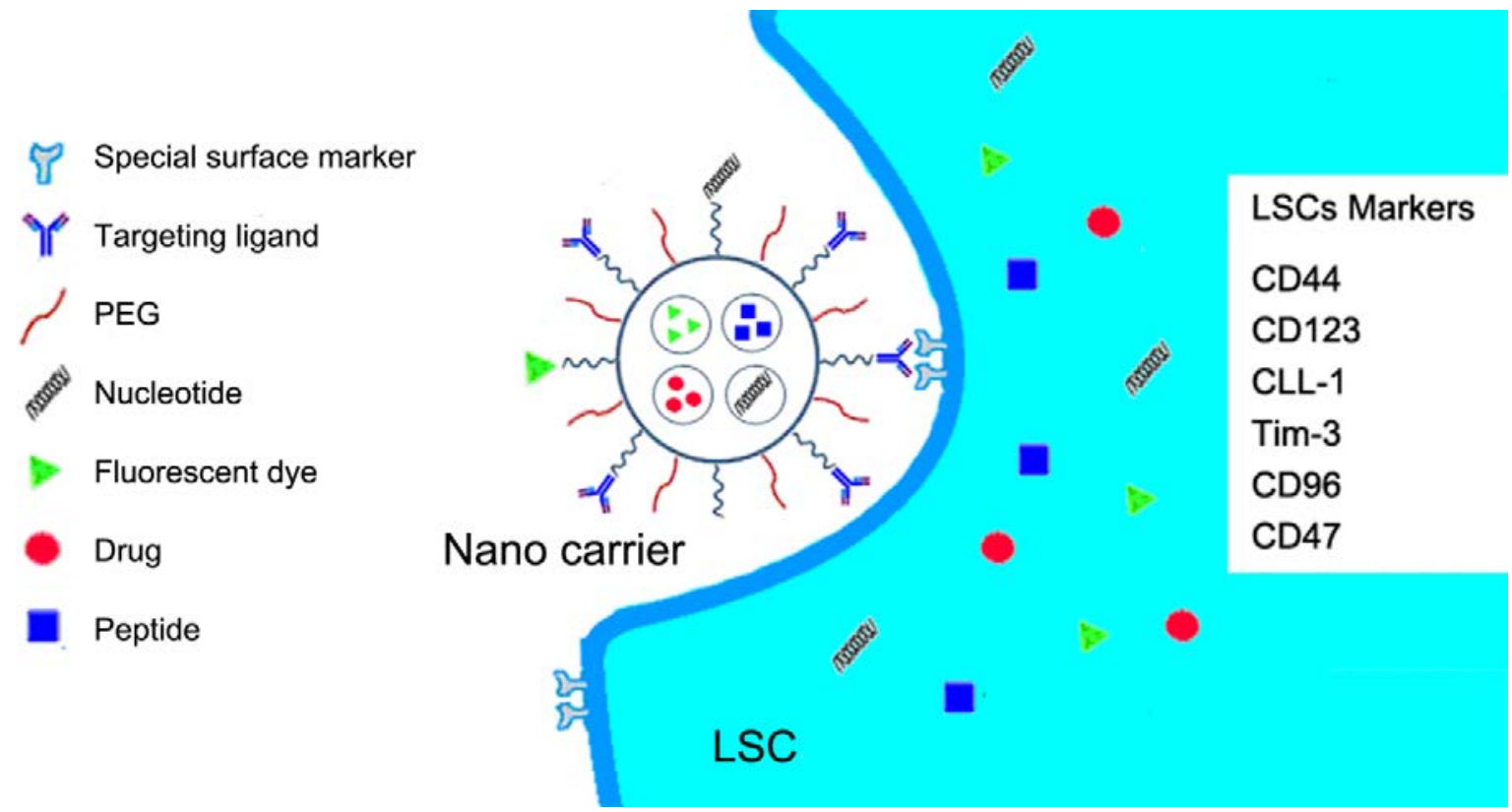

Figure 1: Nanomedicine based Leukemia Stem cell (LSC) treatment, Nanocarriers are conjugated with specific ligands or antibodies to target LSC specific surface markers. Nanocarriers can increase the stability and permeability of their cargos including chemical drugs, peptides, miRNA, or DNA fragments. Nanocarriers are enriched in tumor through Enhanced Permeability and Retention (EPR) effect, and certain modifications such as PEG modification can further increase their tumor targeting specificity. 
Citation: Huang X, Kang X, Zhao M (2017) A Forecast of Targeting Leukemia Stem Cells by Nanomedicine. J Stem Cell Res Ther 7: 385. doi: 10.4172/2157-7633.1000385

Page 3 of 8

\begin{tabular}{|c|c|c|c|c|}
\hline \multicolumn{2}{|l|}{ Target } & \multirow{2}{*}{$\begin{array}{l}\text { Targeting Strategy } \\
\text { CD44 monoclonal antibody H90 } \\
\text { CD123 monoclonal antibody } 7 \mathrm{G} 3 \\
\text { CLL-1 monoclonal antibody } 1075.7 \\
\text { CD47 monoclonal antibody B6H12.2 and BRIC126 } \\
\text { Tim-3 monoclonal antibody ATIK2a }\end{array}$} & \multirow{2}{*}{$\begin{array}{l}\text { Leukemia type } \\
\qquad \begin{array}{l}\text { AML } \\
\text { AML } \\
\text { AML } \\
\text { CML } \\
\text { AML }\end{array}\end{array}$} & \multirow{2}{*}{$\begin{array}{c}\text { Reference } \\
{[21]} \\
{[22]} \\
{[118]} \\
{[35]} \\
{[31]} \\
\end{array}$} \\
\hline $\begin{array}{l}\text { Surface marker antibody/ } \\
\text { ligand }\end{array}$ & $\begin{array}{l}\text { CD44 } \\
\text { CD123 } \\
\text { CLL-1 } \\
\text { CD47 } \\
\text { Tim-3 }\end{array}$ & & & \\
\hline Self-renewal & $\begin{array}{l}\text { Wnt/ß-catenin } \\
\text { Hedgehog } \\
\text { Notch }\end{array}$ & $\begin{array}{l}\text { } \text {-catenin shRNA } \\
\text { Cyclopamine (Hh signaling inhibitor) } \\
\text { Recombinant DII4-Fc Notch ligand }\end{array}$ & $\begin{array}{l}\text { MLL; CML } \\
\text { CML } \\
\text { AML }\end{array}$ & $\begin{array}{c}{[39,40,43]} \\
{[44,45]} \\
{[46]}\end{array}$ \\
\hline Signaling Transduction & $\begin{array}{l}\text { NF-KB } \\
\text { PI3K/AKT/mTOR } \\
\text { LAIR1 }\end{array}$ & $\begin{array}{l}\text { Parthenolide; MG-132; AS602868 } \\
\text { Rapamycin (mTOR kinase inhibitor) } \\
\text { shRNA-226(shRNA specifically targeted lair1 mRNA) }\end{array}$ & $\begin{array}{l}\text { AML } \\
\text { AML } \\
\text { AML }\end{array}$ & $\begin{array}{l}{[47-49]} \\
{[50,51]} \\
{[53]}\end{array}$ \\
\hline Reactive oxygen species & ROS-related drugs & Parthenolide; Fenretinide; Auranofin & $\mathrm{AML} ; \mathrm{CML}$ & {$[48,54-56]$} \\
\hline Heat shock proteins & HSP90 & $\begin{array}{l}\text { 7-AAG (selective inhibitor of HSP90); PU-H71 (small-molecule Hsp90 } \\
\text { inhibitor) }\end{array}$ & $\mathrm{AML} ; \mathrm{CML}$ & {$[58,59]$} \\
\hline Epigenetic mechanism & $\begin{array}{l}\text { Histone deacetylase } \\
\text { miRNA }\end{array}$ & $\begin{array}{l}\text { AR-42 (Histone deacetylase inhibitor); Brd4 (The epigenetic sensor) } \\
\text { shRNAs or JQ1 (the small-molecule Brd4 inhibitor) } \\
\text { antagomiR-126 }\end{array}$ & $\begin{array}{l}\text { AML } \\
\text { AML }\end{array}$ & $\begin{array}{l}{[61,119-121]} \\
{[116] .}\end{array}$ \\
\hline Microenvironment & $\begin{array}{l}\text { CXCR4/CXCL12 } \\
\text { VPS33B }\end{array}$ & $\begin{array}{l}\text { CXCR4 neutralizing antibody } 12 \mathrm{G} 5 \text {; CXCR4 antagonist such as } \\
\text { Plerixafor and AMD3465 } \\
\text { shVPS33B (shRNA specifically targeting VPS33B) }\end{array}$ & $\begin{array}{l}\text { AML } \\
\text { AML }\end{array}$ & $\begin{array}{c}{[69-72]} \\
{[74]}\end{array}$ \\
\hline
\end{tabular}

Table 1: Therapeutic approaches aiming at LSCs.

growth of human MLL leukemic cells or completely abolished the oncogenic potential of MLL-transformed cells [39]. Overall, these evidences indicate that $\mathrm{Wnt} / \beta$-cateninis required for LSCs in multiple types of leukemia but not for homeostasis hematopoiesis, which makes Wnt/ $\beta$-catenin pathway a potential candidate for LSCs targeting therapy. Hedgehog $(\mathrm{Hh})$ signaling pathway plays an important role in sustaining stem cell self-renewal. Deletion of smoothened (Smo), a key transducer of the Hh pathway, or Hh inhibitor treatment can eliminate LSCs in CML. Consistently, constitutive activated Hh signaling leads to augmented LSCs and accelerated disease progress [40]. Conditional Smoothened (Smo) deletion or over-activation has no significant effects on adult HSC self-renewal and function [41]. Notch signaling is silenced in both human and mouse AML cells. Activated Notch signal can induce rapid cell cycle arrest, differentiation, and apoptosis of LSCs in AML models [42].

Several key survival pathways are involved in LSC maintenance by promoting proliferate and preventing apoptosis in LSCs. For example, survival pathway in cancer, NF- $\mathrm{B}$, was found constitutively activated in LSCs. Blocking NF- $\kappa B$ signaling pathway by chemical inhibitors resulted in rapid cell death in LSCs, however normal HSCs were much less effected [43-45]. These data indicated that NF- $\mathrm{\kappa B}$ signaling pathway could serve as a potential target for LSC targeting therapy in AML. The PI3K/AKT/mTOR signaling pathway is activated in most cancers including leukemia. Phosphatase and Tensin Homologue (PTEN), a negative regulator of the PI3K/Akt/mTOR pathway, maintains normal HSCs function and prevents the leukaemogenesis [46,47]. Tissue specific deletion of PTEN in hematopoietic cells led the mice to develop AML and Acute Lymphoid Leukemia (ALL), Rapamycin (mTOR kinase inhibitor) can significantly deplete LSC population in PTEN mutant leukemic mouse model [46,47]. Consistently, PI3K/AKT/mTOR pathway inhibitors such as wortmannin and LY294002 have achieved certain LSC targeting effects in animal models [48]. Recently, Kang et al. showed that The LAIR1-SHP-1-CAMK1-CREB pathway sustains the survival and self-renewal of LSCs in AML but is dispensable for normal hematopoiesis, which highlighted the potential therapeutic value of this pathway in eliminating LSCs in vivo [49].

Reactive oxygen species (ROS), Heat shock proteins (HSP) and Epigenetic modifications have also been suggested in LSC regulation.
High ROS lever results in compromised DNA repair system, increased mutation rates and nuclear damage. Interestingly LSCs have higher ROS level compared to the bulk of leukemia cells and normal HSCs, these ROS tolerance allow LSCs are able to accumulate more mutations for their survival [50]. Several ROS generators, such as Parthenolide, Fenretinide and Auranofin, are used in leukemia therapy. Parthenolide can induce robust apoptosis in primary human AML cells and blast crisis CML cells by increasing their ROS level and repressing their NF- $\kappa B$ activation, however normal hematopoiesis is not effected [44]. Fenretinide and Auranofin, other ROS generators, were proven to eliminate LSCs in CML by selectively increasing their cellular ROS level [51,52]. Chaperone protein, Hsp90, can sustain BCR-ABL activity and promote pathogenesis in CML [53]. Hsp90 is also highly expressed in CD34+ LSCs in AML which sustain Bcl2 protein for anti-apoptosis and enhanced survival of LSCs in AML [54]. Therefore, HSP90 inhibitors hold anti-LSCs potential as they do in solid tumors [55]. Many epigenetic modifiers such as histone deacetylase (HDAC) and DNA methyltransferase (DNMT) inhibitors have been widely used for leukemia treatment [56]. AR-42, a novel histone deacetylase inhibitor, can selectively induce apoptosis of LSCs in AML by inhibiting NF$\kappa \mathrm{B}$ activity and $\mathrm{Hsp} 90$ interaction with its various associated proteins [57]. Overall, the current advances in LSCs studies will develop better therapeutic strategies for leukemia treatment.

\section{Targeting the Niches of LSCs}

The bone marrow microenvironment or niche has provided a protective shelter for normal HSCs [58,59]. However, recent studies suggested that LSCs can share or hijack this refuge for their own survival $[58,60]$. Furthermore, LSCs can even remodel the bone marrow niche for better proliferation and chemotherapy evading [60]. Since LSCs reside in their own protective nice in the BM, theoretically expulsing LSCs from their protective niche would significantly improve the traditional chemotherapy efficiency [61-64]. Therefore, HSC homing signal CXCR4-CXCL12 has been studied for their leukemia treatment effect [58]. Brault et al. found that CXCR4 expression is associated with poor prognosis in AML patients and the interaction between CXCR4 and CXCR12 is critical for the survival and retention of AML cells within the BM niche [65]. CXCR4 up-regulation is associated with increased 
migration and G0-G1 arrest and survival in LSCs of CML [66]. CXCR4/ CXCL12 neutralizing antibodies, CXCR4 antagonist such as plerixafor and AMD3465 were developed for leukemia therapy. Pretreatment of primary human AML cells with neutralizing CXCR4 antibodies or CXCR4 inhibitors blocked AML cell homing to the BM niche in transplanted NOD/SCID mice [65-68]. Recently, researchers found that LSCs can metabolically adapted to adipose tissue niche to evade chemotherapy, which suggested another promising target for LSCs treatment [69]. Autocrine signals are critical for stemness maintenance. Recently, Gu et al. have shown that HSC secreted exosomes promote HSC maintenance and leukemogenesis via VPS33B mediated GDI2/ RAB11A/RAB27A pathway [70]. Overall, current understanding of LSC maintenance mechanisms provides us with opportunities to integrate our theoretical achievements to LSC treatment in pre-clinical practice.

\section{Targeting LSCs by nanomedicine}

Recently, nanomaterials, devices within 100 nanometers, have been used in medical research such as drug delivery and biosensor imaging, which are called Nanomedicine [71,72]. In this section, we will discuss how nanomaterial based drug delivery system, nanocarriers, is used in cancer treatment and its potential application in LSCs targeting.

Chemical drugs used in cancer chemotherapy often have less water solubility and targeting specificity [73]. Compare to traditional drug incorporation system, Nanomedicine based drug deliver can easily cross tight epithelial and endothelial barriers with better targeting specificities and less side effects. Nanomedicine can also help to increase drug stability and solubility, with controlled drug releasing and improved delivery capacities. All these can be helpful for improving current therapeutic strategies in multiple disease treatments $[6,74]$. For example, Layer-by-Layer (LbL) Nanocarriers can selectively target tumor by recognizing hypoxic tumor $\mathrm{PH}$ and hualuronan modification can recognize CD44 [75], a CSC surface markers. Thus, hualuronan modified LbL Nanocarriers significantly increased their tumor targeting efficiency [76]. Furthermore, Nanocarrier system has enhanced drug stability in vivo, because these nanomaterial capsules have improved biocompatibility, which can protect chemical drugs from degradation and clearance. For example, nanocarriers coated with PEG (polyethylene glycol), can effectively repress the endocytosis of mononuclear phagocyte and prolong the drug retention time in blood [77]. The nanocarrier based drug delivery system is especially useful for unstable biological drugs such as siRNA and plasmid DNA. Researchers found that lipopeptide modified nanoparticles can serve as siRNA carriers for gene silencing in vivo with wide therapeutic index [78]. Compared to traditional viral siRNA deliver system, this Nanocarrier system has much lower biosafety risk and improved efficiency with lower cost $[34,78]$. As a result, the nanocarrier encapsulated drugs have much improved stability compared to free drugs which dramatically enhanced their in vivo cancer therapy efficacy. For example, Doxil, a liposomal based nanocarrier for doxorubicin, exhibited more than 100 times longer half-life in blood circulation than that of doxorubicin alone, which dramatically reduced cardio toxicity caused by doxorubicin treatment [79]. Furthermore, multiple nanocarriers have enhanced drug accumulation in the bulk of tumor than normal tissues such as liver, spleen and heart via enhanced permeability and retention (EPR) effect. Because tumor vessels are usually poorly aligned defective endothelial cells, lacking a smooth muscle layer and effective lymphatic drainage, which lead to abnormal molecular and fluid transport dynamics, especially for macromolecular drugs. This phenomenon is referred to the EPR effect, especially occurred in most solid tumors [80-87]. Because of their nano scale size, the nanocarrier based drug delivery system can pass through blood-brain barrier $[88,89]$. Investigators found that those carriers can either open up a tight junction or undergo endocytosis to cross the blood-brain barrier, which prevents the passage of most traditional drugs [90-95].

Recently, switchable nanocarriers have been developed, in which the drug unloading is controlled by the changes of temperature, $\mathrm{pH}$, light, ultrasound, or magnetic field $[96,97]$. These advances will significantly improve the drug deliver efficiency and specificity for cancer therapy.

Although multiple LSCs targeting strategies have been developed, the way of efficiently delivering drug in vivo is still challenging. Therefore, Nanomedicine provides a great opportunity for CSC and LSC targeting in pre-clinic applications. CD44, a major receptor for Hyaluronan (HA), is highly expressed in CSCs and LSCs. Therefore, the HA/CD44 interaction can serve as a potential target for CSC and LSC targeting therapy $[98,99]$. HA incorporated nanocarriers can deliver traditional chemotherapeutic drugs, such as doxorubicin and cyclosporine, to successfully target CD44 expressing CSCs both in vitro and in vivo [75]. This Nanomedicine based CSC targeting strategies have achieved prolonged survival in multiple animal cancer models including AML [76, 100-103]. Antibody incorporated nanocarriers have also been used for CSC targeting. For example, anti-CD133 incorporated nanocarrier can deliver pacilitaxel to destroy liver CSCs in animal models [104,105]. Interesting, some nanomaterials have high CSC affinity although the potential mechanisms are unclear. For example, graphene oxide can selectively induce CSC differentiation by inhibiting multiple key pathways for CSC self-renewal including WNT, Notch and STAT-signaling. Since graphene oxide is non-toxic, this therapeutic strategy is promising for CSC eradication [106]. The metallofullerenol nanomaterial, Gd@C82(OH)22, can block epithelialto-mesenchymal transition with resultant efficient elimination of breast CSCs, potentially through a bi-potent inhibition of HIF- $1 \alpha$ and TGF- $\beta$ activities [107].

Besides traditional chemotherapy, Nanomedicine can also improve the therapeutic efficiency of recent developed cancer treatment strategies such as hyperthermia therapy and Photodynamic Therapy (PDT). For example, gold-coated nanoshells can increase the sensitivity of CSCs to hyperthermia therapy in breast cancer xenograft model [108-110]. Barth et al. reported Calcium Phosphosilicate Nanoparticles (CPSNPs) can encapsulate nearinfrared fluoroprobe Indocyanine Green (ICG) for diagnostic imaging and drug delivery. For LSC targeting, ICGCPSNPs reacted with antibodies to target CD117 or CD96 expressing LSCs. They found that their nanocomplexes accumulated in LSCs, dramatically improved PDT efficacy and resulted in 29\% disease-free survival in mouse leukemia model [111].

Taking advantage of the protective role of nanorarriers, unstable nucleotide drugs, such as siRNAs and miRNAs, can be applied for in vivo cancer treatment. siRNA has been considered as one of the most promising candidate for gene therapy in cancer treatment, however their instability significantly limited their clinical applications [112]. Recently, Dorrance et al. have successfully delivered antagomiR-126 into AML mouse models by using nanocarrier, in which LSCs were depleted [113]. Another advantage of nanocarrier based delivery system is that it can transport multiple drugs simultaneously. Palamà et al. have shown that nanocarriers can deliver Imatinibmesylate and doxorubicin simultaneously into CML cells. Such combo treatment achieved much improved efficacy than single drug treatment [114]. 


\section{Future Perspective}

Nanomedicine based LSC targeting strategies have opened a novel avenue for leukemia treatment. Nanocarriers can specifically deliver traditional chemotherapeutic drugs and gene therapy drugs such as siRNA and even Cripr-Cas9 gene editing tools into LSCs. The accomplishment of these strategies will significantly reduce the risk of leukemia recurrence. Several research directions need to be further explored by us to achieve this ultimate goal.

The first aim is to distinguish normal HSCs with LSCs. Although in previous studies, LSCs are thought to share the similar cell surface markers and intrinsic regulatory signals with normal HSCs. Recent studies have uncovered several key signals that can distinguish LSCs with normal HSCs [115]. Those cell surface markers such as CD44 and CD133, and intrinsic molecules, like PTEN and $\beta$-catenin can be used as potential drug targets for LSC targeting therapy. In the future, how to develop better strategies to target these candidates would be critical, fortunately Nanomedicine has already shown its promising applicable prospects.

The second aim is to improve the in vivo targeting efficiency. Although accumulating studies have discovered critical drug targets for CSC self-renewal regulation, the complete cure of the cancer has not been achieved. The main reason is that most drugs, especially those unstable chemical drugs, cannot be efficiently delivered into tumor. To compromise the instability issue, physicians have to increase the drug dosage, which unfortunately leads to enhanced cytotoxicity to normal tissues in cancer patients. Therefore, nanocarriers provide one of the best solutions to solve this issue, which may remarkably improve cancer treatment in the near future.

The third aim is to improve the biological drug treatment efficiency. Biological drugs, such as special peptides, miRNA and siRNA, have been proved with great advantage for cancer treatment. However, their limited stability hindered their clinical applications. Recently several nanocarriers have shown promising results in biological drug delivery in vivo (Figure1) $[113,116]$.

Overall, LSCs studies have discovered increasing LSC targeting candidates with great clinical potential. How to efficiently target those candidates for improving cancer treatment would be critical. Currently, Nanomedicine has been proved with promising success in CSC and LSC targeting treatments.

\section{Author Contributions}

$\mathrm{XH}$ wrote the manuscript. XK and MZ provided critical comments and revised the manuscript.

\section{Funding}

MZ is supported by Zhongshan School of Medicine, Sun Yat-sen University and the Thousand Talents Plan in China.

\section{References}

1. Scadden DT (2004) Cancer stem cells refined. Nat Immunol 5: 701-703. [PubMed]

2. Hanahan D, Weinberg RA (2000) The hallmarks of cancer. Cell 100: 57-70. [PubMed]

3. Hanahan D, Weinberg RA (2011) Hallmarks of cancer: the next generation. Cell 144: 646-74. [PubMed]

4. Health Nlo (2006) National Institute of Health roadmap for medical research. Nanomedicine, Bethesda, Maryland.
5. Shi J, Kantoff PW, Wooster R, Farokhzad OC (2017) Cancer nanomedicine: progress, challenges and opportunities. Nat Rev Cancer 17: 20-37. [PubMed]

6. Lutz C, Hoang VT, Buss E, Ho AD (2013) Identifying leukemia stem cells--is it feasible and does it matter? Cancer Lett 338: 10-14. [PubMed]

7. Chavez-Gonzalez A, Bakhshinejad B, Pakravan K, Guzman ML, Babashah S (2016) Novel strategies for targeting leukemia stem cells: sounding the death knell for blood cancer. Cell Oncol (Dordr) 40: 1-20. [PubMed]

8. Pollyea DA, Gutman JA, Gore L, Smith CA, Jordan CT (2014) Targeting acute myeloid leukemia stem cells: a review and principles for the development of clinical trials. Haematologica 99: 1277-84. [PubMed]

9. Martin PJ, Najfeld V, Hansen JA, Penfold GK, Jacobson RJ, et al. (1980) Involvement of the B-lymphoid system in chronic myelogenous leukaemia. Nature 287: 49-50.

10. Jonas D, Lubbert M, Kawasaki ES, Henke M, Bross KJ, et al. (1992) Clonal analysis of bcr-abl rearrangement in T lymphocytes from patients with chronic myelogenous leukemia. Blood 79: 1017-1023. [PubMed]

11. Shlush LI, Zandi S, Mitchell A, Chen WC, Brandwein JM, et al. (2014) Identification of pre-leukaemic haematopoietic stem cells in acute leukaemia. Nature 506: 328-233. [PubMed]

12. Sloma I, Jiang X, Eaves AC, Eaves CJ (2010) Insights into the stem cells of chronic myeloid leukemia. Leukemia 24: 1823-1833. [PubMed]

13. Bonnet D, Dick JE (1997) Human acute myeloid leukemia is organized as a hierarchy that originates from a primitive hematopoietic cell. Nat Med 3: 730737. [PubMed]

14. Jin L, Hope KJ, Zhai Q, Smadja-Joffe F, Dick JE (2006) Targeting of CD44 eradicates human acute myeloid leukemic stem cells. Nat Med 12: 1167-1174. [PubMed]

15. Jin L, Lee EM, Ramshaw HS, Busfield SJ, Peoppl AG, Wilkinson L, et al. (2009) Monoclonal antibody-mediated targeting of CD123, IL-3 receptor alpha chain eliminates human acute myeloid leukemic stem cells. Cell stem cell 5: 31-42. [PubMed]

16. Bakker $A B$, van den Oudenrijn S, Bakker AQ, Feller N, van Meijer $M$, et al. (2004) C-type lectin-like molecule-1: a novel myeloid cell surface marker associated with acute myeloid leukemia. Cancer Res 64: 8443-8450. [PubMed]

17. Han G, Chen G, Shen B, Li Y (2013) Tim-3: an activation marker and activation limiter of innate immune cells. Front Immunol 4: 449. [PubMed]

18. Hosen N, Park CY, Tatsumi N, Oji Y, Sugiyama H, et al. (2007) CD96 is a leukemic stem cell-specific marker in human acute myeloid leukemia. Proc Natl Acad Sci USA 104: 11008-110013. [PubMed]

19. Majeti R, Chao MP, Alizadeh AA, Pang WW, Jaiswal S, et al (2009) CD47 is an adverse prognostic factor and therapeutic antibody target on human acute myeloid leukemia stem cells. Cell 138: 286-299. [PubMed]

20. Zoller M (2011) CD44: can a cancer-initiating cell profit from an abundantly expressed molecule? Nat Rev Cancer 11: 254-267. [PubMed]

21. Jordan CT, Upchurch D, Szilvassy SJ, Guzman ML, Howard DS, et al. (2000) The interleukin-3 receptor alpha chain is a unique marker for human acute myelogenous leukemia stem cells. Leukemia 14: 1777-1784. [PubMed]

22. Florian S, Sonneck K, Hauswirth AW, Krauth MT, Schernthaner GH, et al. (2006) Detection of molecular targets on the surface of CD34+/CD38-- stem cells in various myeloid malignancies. Leuk Lymphoma 47: 207-222. [PubMed]

23. van Rhenen A, van Dongen GA, Kelder A, Rombouts EJ, Feller N, et al. (2007) The novel AML stem cell associated antigen CLL-1 aids in discrimination between normal and leukemic stem cells. Blood 110: 2659-2666. [PubMed]

24. Kikushige Y, Shima T, Takayanagi S, Urata S, Miyamoto T, et al. (2010) TIM-3 is a promising target to selectively kill acute myeloid leukemia stem cells. Cell stem cell 7: 708-717. [PubMed]

25. Jan M, Chao MP, Cha AC, Alizadeh AA, Gentles AJ, et al. (2011) Prospective separation of normal and leukemic stem cells based on differential expression of TIM3, a human acute myeloid leukemia stem cell marker. Proc Natl Acad Sci USA 108: 5009-5014. [PubMed]

26. Saito Y, Kitamura H, Hijikata A, Tomizawa-Murasawa M, Tanaka S, et al. (2010) Identification of therapeutic targets for quiescent, chemotherapy-resistant human leukemia stem cells. Sci Transl Med 2: 17. [PubMed] 
27. Huang R, Rofstad EK (2016) Cancer stem cells (CSCs), cervical CSCs and targeted therapies. Oncotarget [PubMed]

28. Imai K, Takaoka A (2006) Comparing antibody and small-molecule therapies for cancer. Nat Rev Cancer 6: 714-727. [PubMed]

29. Liesveld J (2012) Targeting myelogenous leukemia stem cells: role of the circulation. Frontiers Oncology 2: 86. [PubMed]

30. Chao MP, Alizadeh AA, Tang C, Jan M, Weissman-Tsukamoto R, et al. (2011) Therapeutic antibody targeting of CD47 eliminates human acute lymphoblastic leukemia. Cancer Res 71: 1374-1384. [PubMed]

31. Hong D, Gupta R, Ancliff P, Atzberger A, Brown J, et al. (2008) Initiating and cancer-propagating cells in TEL-AML1-associated childhood leukemia. Science 319: 336-339. [PubMed]

32. Horton SJ, Huntly BJ (2012) Recent advances in acute myeloid leukemia stem cell biology. Haematologica 97: 966-974. [PubMed]

33. Velluto D, Thomas SN, Simeoni E, Swartz MA, Hubbell JA (2011) PEG-b-PPSb-PEI micelles and PEG-b-PPS/PEG-b-PPS-b-PEI mixed micelles as nonviral vectors for plasmid DNA: tumor immunotoxicity in B16F10 melanoma. Biomaterials 32: 9839-9847. [PubMed]

34. Zhao C, Blum J, Chen A, Kwon HY, Jung SH, et al. (2007) Loss of beta-catenin impairs the renewal of normal and CML stem cells in vivo. Cancer Cell 12: 528-541. [PubMed]

35. Zhao M, Li L (2015) Regulation of hematopoietic stem cells in the niche. Science China Life sciences 58: 1209-1215. [PubMed]

36. Koch U, Wilson A, Cobas M, Kemler R, Macdonald HR, et al. (2008) Simultaneous loss of beta- and gamma-catenin does not perturb hematopoiesis or lymphopoiesis. Blood 111: 160-164. [PubMed]

37. Jeannet G, Scheller M, Scarpellino L, Duboux S, Gardiol N, et al. (2008) Longterm, multilineage hematopoiesis occurs in the combined absence of betacatenin and gamma-catenin. Blood 111: 142-149. [PubMed]

38. Yeung J, Esposito MT, Gandillet A, Zeisig BB, Griessinger E, et al. (2010) betaCatenin mediates the establishment and drug resistance of MLL leukemic stem cells. Cancer Cell 18: 606-618. [PubMed]

39. Zhao C, Chen A, Jamieson CH, Fereshteh M, Abrahamsson A, et al. (2009) Hedgehog signalling is essential for maintenance of cancer stem cells in myeloid leukaemia. Nature 458: 776-779.

40. Gao J, Graves S, Koch U, Liu S, Jankovic V, et al. (2009) Hedgehog signaling is dispensable for adult hematopoietic stem cell function. Cell Stem Cell 4: 548558. [PubMed]

41. Lobry C, Ntziachristos P, Ndiaye-Lobry D, Oh P, Cimmino L, et al. (2013) Notch pathway activation targets $A M L$-initiating cell homeostasis and differentiation. $J$ Exp Med 210: 301-319. [PubMed]

42. Guzman ML, Neering SJ, Upchurch D, Grimes B, Howard DS, et al. (2001) Nuclear factor-kappaB is constitutively activated in primitive human acute myelogenous leukemia cells. Blood 98: 2301-2307. [PubMed]

43. Guzman ML, Rossi RM, Karnischky L, Li X, Peterson DR, et al. (2005) The sesquiterpene lactone parthenolide induces apoptosis of human acute myelogenous leukemia stem and progenitor cells. Blood 105: 4163-4169. [PubMed]

44. Frelin C, Imbert V, Griessinger E, Peyron AC, Rochet N, et al. (2005) Targeting NF-kappaB activation via pharmacologic inhibition of IKK2-induced apoptosis of human acute myeloid leukemia cells. Blood 105: 804-811. [PubMed]

45. Yilmaz OH, Valdez R, Theisen BK, Guo W, Ferguson DO, et al. (2006) Pten dependence distinguishes haematopoietic stem cells from leukaemia-initiating cells. Nature 441: 475-482. [PubMed]

46. Zhang J, Grindley JC, Yin T, Jayasinghe S, He XC, et al. (2006) PTEN maintains haematopoietic stem cells and acts in lineage choice and leukaemia prevention. Nature 441: 518-522. [PubMed]

47. Hu Y, Li S (2016) Survival regulation of leukemia stem cells. Cell Mol Life Sci 73: 1039-1050. [PubMed]

48. Kang X, Lu Z, Cui C, Deng M, Fan Y, et al. (2015) The ITIM-containing receptor LAIR1 is essential for acute myeloid leukaemia development. Nature cell biology 17: 665-677. [PubMed]
49. Nieborowska-Skorska M, Kopinski PK, Ray R, Hoser G, Ngaba D, et al. (2012) Rac2-MRC-clll-generated ROS cause genomic instability in chronic myeloid leukemia stem cells and primitive progenitors. Blood 119: 4253-4263. [PubMed]

50. Chen X, Shi X, Zhao C, Li X, Lan X, et al. (2014) Anti-rheumatic agent auranofin induced apoptosis in chronic myeloid leukemia cells resistant to imatinib through both Bcr/Abl-dependent and -independent mechanisms. Oncotarget 5: 9118-9132.

51. Du Y, Xia Y, Pan X, Chen Z, Wang A, Wang K, et al. (2014) Fenretinide targets chronic myeloid leukemia stem/progenitor cells by regulation of redox signaling. Antioxid Redox Signal 20: 1866-80. [PubMed]

52. Moulick K, Ahn JH, Zong H, Rodina A, Cerchietti L, et al. (2011) Affinity-based proteomics reveal cancer-specific networks coordinated by Hsp90. Nat Chem Biol 7: 818-826. [PubMed]

53. Flandrin P, Guyotat D, Duval A, Cornillon J, Tavernier E, et al. (2008) Significance of heat-shock protein (HSP) 90 expression in acute myeloid leukemia cells. Cell Stress Chaperones 13: 357-364. [PubMed]

54. Zong H, Gozman A, Caldas-Lopes E, Taldone T, Sturgill E, et al. (2015) A Hyperactive Signalosome in Acute Myeloid Leukemia Drives Addiction to a Tumor-Specific Hsp90 Species. Cell Rep 13: 2159-2173. [PubMed]

55. Ding L, Ley TJ, Larson DE, Miller CA, Koboldt DC, et al. (2012) Clonal evolution in relapsed acute myeloid leukaemia revealed by whole-genome sequencing Nature 481: 506-510. [PubMed]

56. Guzman ML, Yang N, Sharma KK, Balys M, Corbett CA, et al. (2014) Selective activity of the histone deacetylase inhibitor AR-42 against leukemia stem cells: a novel potential strategy in acute myelogenous leukemia. Mol Cancer Ther 13 1979-1990. [PubMed]

57. Konopleva MY, Jordan CT (2011) Leukemia stem cells and microenvironment: biology and therapeutic targeting. J Clin Oncol 29: 591-599. [PubMed]

58. Agarwal P, Bhatia R (2015) Influence of Bone Marrow Microenvironment on Leukemic Stem Cells: Breaking Up an Intimate Relationship. Adv Cancer Res 127: 227-252. [PubMed]

59. Duan CW, Shi J, Chen J, Wang B, Yu YH, et al. (2014) Leukemia propagating cells rebuild an evolving niche in response to therapy. Cancer Cell 25: 778-793. [PubMed]

60. Colmone A, Amorim M, Pontier AL, Wang S, Jablonski E, Sipkins DA (2008) Leukemic cells create bone marrow niches that disrupt the behavior of normal hematopoietic progenitor cells. Science 322: 1861-1865. [PubMed]

61. Schepers K, Pietras EM, Reynaud D, Flach J, Binnewies M, et al. (2013) Myeloproliferative neoplasia remodels the endosteal bone marrow niche into a self-reinforcing leukemic niche. Cell Stem Cell 13: 285-299. [PubMed]

62. Zhang B, Ho YW, Huang Q, Maeda T, Lin A, et al. (2012) Altered microenvironmental regulation of leukemic and normal stem cells in chronic myelogenous leukemia. Cancer cell 21: 577-592. [PubMed]

63. Cheng H, Hao S, Liu Y, Pang Y, Ma S, et al. (2015) Leukemic marrow infiltration reveals a novel role for Egr3 as a potent inhibitor of normal hematopoietic stem cell proliferation. Blood 126: 1302-1313. [PubMed]

64. Brault L, Rovo A, Decker S, Dierks C, Tzankov A (2014) CXCR4-SERINE339 regulates cellular adhesion, retention and mobilization, and is a marker for poor prognosis in acute myeloid leukemia. Leukemia 28: 566-576. [PubMed]

65. Jin L, Tabe Y, Konoplev S, Xu Y, Leysath CE, et al. (2008) CXCR4 up-regulation by imatinib induces chronic myelogenous leukemia (CML) cell migration to bone marrow stroma and promotes survival of quiescent CML cells. Mol Cance Ther 7: 48-58. [PubMed]

66. Weisberg E, Azab AK, Manley PW, Kung AL, Christie AL, et al. (2012) Inhibition of CXCR4 in CML cells disrupts their interaction with the bone marrow microenvironment and sensitizes them to nilotinib. Leukemia 26: 985-990. [PubMed]

67. Tavor S, Petit I, Porozov S, Avigdor A, Dar A, et al. (2004) CXCR4 regulates migration and development of human acute myelogenous leukemia stem cells in transplanted NOD/SCID mice. Cancer Res 64: 2817-2824. [PubMed]

68. Ye H, Adane B, Khan N, Sullivan T, Minhajuddin M, et al. (2016) Leukemic Stem Cells Evade Chemotherapy by Metabolic Adaptation to an Adipose Tissue Niche. Cell Stem Cell 19: 23-37. [PubMed] 
69. Gu H, Chen C, Hao X, Wang C, Zhang X, et al. (2016) Sorting protein VPS33B regulates exosomal autocrine signaling to mediate hematopoiesis and leukemogenesis. J Clin Invest 126: 4537-4553. [PubMed]

70. Boulaiz H, Alvarez PJ, Ramirez A, Marchal JA, Prados J, et al. (2011) Nanomedicine: application areas and development prospects. Int J Mol Sci 12 3303-3321. [PubMed]

71. Saha M (2009) Nanomedicine: promising tiny machine for the healthcare in future-a review. Oman Med J 24: 242-247. [PubMed]

72. Cho K, Wang X, Nie S, Chen ZG, Shin DM (2008) Therapeutic nanoparticles for drug delivery in cancer. Clin Cancer Res 14: 1310-1316. [PubMed]

73. Gharpure KM, Wu SY, Li C, Lopez-Berestein G, Sood AK (2015) Nanotechnology: Future of Oncotherapy. Clin Cancer Res 21: 3121-3130. [PubMed]

74. Misra S, Heldin P, Hascall VC, Karamanos NK, Skandalis SS, et al. (2011) Hyaluronan-CD44 interactions as potential targets for cancer therapy. FEBS J 278: 1429-1443. [PubMed]

75. Dreaden EC, Morton SW, Shopsowitz KE, Choi JH, Deng ZJ, et al. (2014) Bimodal tumor-targeting from microenvironment responsive hyaluronan layerby-layer (LbL) nanoparticles. ACS Nano 8: 8374-8382. [PubMed]

76. Walkey CD, Olsen JB, Guo H, Emili A, Chan WC (2012) Nanoparticle size and surface chemistry determine serum protein adsorption and macrophage uptake. J Am Chem Soc 134: 2139-2147. [PubMed]

77. Dong Y, Love KT, Dorkin JR, Sirirungruang S, Zhang Y, et al. (2014) Lipopeptide nanoparticles for potent and selective siRNA delivery in rodents and nonhuman primates. Proc Natl Acad Sci USA 111: 3955-3960. [PubMed]

78. Barenholz Y (2012) Doxil(R)--the first FDA-approved nano-drug: lessons learned. J Control Release 160: 117-134. [PubMed]

79. Roy K, Kanwar RK, Krishnakumar S, Cheung CH, Kanwar JR (2015) Competitive inhibition of survivin using a cell-permeable recombinant protein induces cancer-specific apoptosis in colon cancer model. Int J Nanomed 10: 1019-1043. [PubMed]

80. Zhong Y, Zhang J, Cheng R, Deng C, Meng F, et al. (2015) Reversibly crosslinked hyaluronic acid nanoparticles for active targeting and intelligent delivery of doxorubicin to drug resistant CD44+ human breast tumor xenografts J Control Release 205: 144-154. [PubMed]

81. Liu Y, Sun J, Lian H, Cao W, Wang Y (2014) Folate and CD44 receptors dualtargeting hydrophobized hyaluronic acid paclitaxel-loaded polymeric micelles for overcoming multidrug resistance and improving tumor distribution. J Pharm Sci 103: 1538-1547. [PubMed]

82. Gu J, Fang X, Hao J, Sha X (2015) Reversal of P-glycoprotein-mediated multidrug resistance by CD44 antibody-targeted nanocomplexes for short hairpin RNA-encoding plasmid DNA delivery. Biomaterials 45: 99-114. [PubMed]

83. Jin C, Yang Z, Yang J, Li H, He Y, et al. (2014) Paclitaxel-loaded nanoparticles decorated with anti-CD133 antibody: a targeted therapy for liver cancer stem cells. J Nano Res 16: 1-15.

84. Krishnamurthy S, Ng VW, Gao S, Tan MH, Yang YY (2014) Phenformin-loaded polymeric micelles for targeting both cancer cells and cancer stem cells in vitro and in vivo. Biomaterials 35: 9177-9186. [PubMed]

85. Almeida JP, Chen AL, Foster A, Drezek R (2011) In vivo biodistribution of nanoparticles. Nanomedicine (Lond) 6: 815-835. [PubMed]

86. Greish K (2010) Enhanced permeability and retention (EPR) effect for anticancer nanomedicine drug targeting. Methods Mol Biol 624: 25-37. [PubMed]

87. Mittal D, Md S, Hasan Q, Fazil M, Ali A, et al. (2016) Brain targeted nanoparticulate drug delivery system of rasagiline via intranasal route. Drug Delivery 23: 130-139. [PubMed]

88. Zhang L, Yao HJ, Yu Y, Zhang Y, Li RJ, et al. (2012) Mitochondrial targeting liposomes incorporating daunorubicin and quinacrine for treatment of relapsed breast cancer arising from cancer stem cells. Biomaterials 33: 565-582. [PubMed]

89. Malvindi MA, Di Corato R, Curcio A, Melisi D, Rimoli MG, et al. (2011) Multiple functionalization of fluorescent nanoparticles for specific biolabeling and drug delivery of dopamine. Nanoscale 3: 5110-5119. [PubMed]

90. Hu K, Shi Y, Jiang W, Han J, Huang S, et al. (2011) Lactoferrin conjugated PEG-PLGA nanoparticles for brain delivery: preparation, characterization and efficacy in Parkinson's disease. Int J Pharm 415: 273-283. [PubMed]
91. Bramini M, Ye D, Hallerbach A, Nic Raghnaill M, Salvati A, et al. (2014) Imaging approach to mechanistic study of nanoparticle interactions with the blood-brain barrier. ACS Nano 8: 4304-4312. [PubMed]

92. Etame AB, Smith CA, Chan WC, Rutka JT (2011) Design and potential application of PEGylated gold nanoparticles with size-dependent permeation through brain microvasculature. Nanomedicine 7: 992-1000. [PubMed]

93. Guerrero S, Araya E, Fiedler JL, Arias JI, Adura C, et al. (2010) Improving the brain delivery of gold nanoparticles by conjugation with an amphipathic peptide. Nanomedicine (Lond) 5: 897-913. [PubMed]

94. Zensi A, Begley D, Pontikis C, Legros C, Mihoreanu L, et al. (2009) Albumin nanoparticles targeted with Apo E enter the CNS by transcytosis and are delivered to neurones. J Control Release 137: 78-86. [PubMed]

95. Yu B, Tai HC, Xue W, Lee LJ, Lee RJ (2010) Receptor-targeted nanocarriers for therapeutic delivery to cancer. Mol Membr Biol 27: 286-2898. [PubMed]

96. Mura S, Nicolas J, Couvreur P (2013) Stimuli-responsive nanocarriers for drug delivery. Nat Mater 12: 991-1003.

97. Ebben JD, Treisman DM, Zorniak M, Kutty RG, Clark PA, et al. (2010) The cancer stem cell paradigm: a new understanding of tumor development and treatment. Exp Opin Ther Target 14: 621-32. [PubMed]

98. Aguilar-Gallardo C, Rutledge EC, Martinez-Arroyo AM, Hidalgo JJ, Domingo S, et al. (2012) Overcoming challenges of ovarian cancer stem cells: nove therapeutic approaches. Stem Cell Rev 8: 994-1010. [PubMed]

99. Cho HJ, Yoon HY, Koo H, Ko SH, Shim JS, et al. (2011) Self-assembled nanoparticles based on hyaluronic acid-ceramide (HA-CE) and Pluronic(R) for tumor-targeted delivery of docetaxel. Biomater 32: 7181-7190. [PubMed]

100. Han NK, Shin DH, Kim JS, Weon KY, Jang CY, et al. (2016) Hyaluronanconjugated liposomes encapsulating gemcitabine for breast cancer stem cells. Int J Nanomed 11: 1413-1425. [PubMed]

101. Hu K, Zhou H, Liu Y, Liu Z, Liu J, et al. (2015) Hyaluronic acid functional amphipathic and redox-responsive polymer particles for the co-delivery of doxorubicin and cyclopamine to eradicate breast cancer cells and cancer stem cells. Nanoscale 7: 8607-8618. [PubMed]

102. Yang X, lyer AK, Singh A, Choy E, Hornicek FJ, et al. (2015) MDR1 siRNA loaded hyaluronic acid-based CD44 targeted nanoparticle systems circumvent paclitaxel resistance in ovarian cancer. Sci Rep 5: 8509. [PubMed]

103. Singh SK, Hawkins C, Clarke ID, Squire JA, Bayani J, et al. (2004) Identification of human brain tumour initiating cells. Nature 432: 396-401. [PubMed]

104. Bourseau-Guilmain E, Bejaud J, Griveau A, Lautram N, Hindre F, et al. (2012) Development and characterization of immuno-nanocarriers targeting the cancer stem cell marker AC133. Int J Pharm 423: 93-101. [PubMed]

105. Fiorillo M, Verre AF, Iliut M, Peiris-Pages M, Ozsvari B, et al. (2015) Graphene oxide selectively targets cancer stem cells, across multiple tumor types: implications for non-toxic cancer treatment, via "differentiation-based nanotherapy". Oncotarget 6: 3553-3562. [PubMed]

106. Liu Y, Chen C, Qian P, Lu X, Sun B, et al. (2015) Gd-metallofullerenol nanomaterial as non-toxic breast cancer stem cell-specific inhibitor. Nat Commun 6: 5988. [PubMed]

107. Dewhirst MW, Vujaskovic Z, Jones E, Thrall D (2005) Re-setting the biologic rationale for thermal therapy. Int J Hyperthermia 21: 779-790. [PubMed]

108. Horsman MR, Overgaard J (2007) Hyperthermia: a potent enhancer of radiotherapy. Clin Oncol (R Coll Radiol) 19: 418-426. [PubMed]

109. Atkinson RL, Zhang M, Diagaradjane P, Peddibhotla S, Contreras A, et al. (2010) Thermal enhancement with optically activated gold nanoshells sensitizes breast cancer stem cells to radiation therapy. Sci Translat Med 2 : 55-79. [PubMed]

110. Barth BM, I Altinoğlu E, Shanmugavelandy SS, Kaiser JM, Crespo-Gonzalez D, et al. (2011) Targeted indocyanine-green-loaded calcium phosphosilicate nanoparticles for in vivo photodynamic therapy of leukemia. ACS Nano 5 : 5325-5337. [PubMed]

111. Rahimy E, Kuo SZ, Ongkeko WM (2014) Evaluation of non-coding RNAs as potential targets in head and neck squamous cell carcinoma cancer stem cells. Curr Drug Target 15: 1247-1260. [PubMed] 
Citation: Huang X, Kang X, Zhao M (2017) A Forecast of Targeting Leukemia Stem Cells by Nanomedicine. J Stem Cell Res Ther 7: 385. doi: 10.4172/2157-7633.1000385

Page 8 of 8

112. Dorrance AM, Neviani P, Ferenchak GJ, Huang X, Nicolet D, Maharry KS et al. (2015) Targeting leukemia stem cells in vivo with antagomiR-126 nanoparticles in acute myeloid leukemia. Leukemia 29: 2143-2153. [PubMed]

113. Palama IE, Cortese B, D'Amone S, Arcadio V, Gigli G (2015) Coupled delivery of imatinib mesylate and doxorubicin with nanoscaled polymeric vectors for a sustained downregulation of BCR-ABL in chronic myeloid leukemia. Biomater Sci 3: 361-372.

114. Guo J, Cahill MR, McKenna SL, O'Driscoll CM (2014) Biomimetic nanoparticles for siRNA delivery in the treatment of leukaemia. Biotechnol Adv 32: 13961409. [PubMed]

115. Zhao X, Singh S, Pardoux C, Zhao J, Hsi ED, et al. (2010) Targeting C-type lectin-like molecule-1 for antibody-mediated immunotherapy in acute myeloid leukemia. Haematologica 95: 71-78. [PubMed]

116. Blobel GA, Kalota A, Sanchez PV, Carroll M (2011) Short hairpin RNA screen reveals bromodomain proteins as novel targets in acute myeloid leukemia Cancer Cell 20: 287-288. [PubMed]

117. Zuber J, Shi J, Wang E, Rappaport AR, Herrmann H, et al. (2011) RNAi screen identifies Brd4 as a therapeutic target in acute myeloid leukaemia. Nature 478 : 524-528.

118. Filippakopoulos P, Qi J, Picaud S, Shen Y, Smith WB, et al. (2010) Selective inhibition of BET bromodomains. Nature 468: 1067-1073. [PubMed] 